\title{
Abiotic and biotic control of methanol exchanges in a temperate mixed forest
}

\author{
Q. Laffineur ${ }^{1}$, M. Aubinet ${ }^{1}$, N. Schoon ${ }^{2}$, C. Amelynck ${ }^{2}$, J.-F. Müller ${ }^{2}$, J. Dewulf ${ }^{3}$, H. Van Langenhove ${ }^{3}$, K. Steppe ${ }^{4}$, \\ and B. Heinesch ${ }^{1}$ \\ ${ }^{1}$ Unité de Physique des Biosystèmes, Gembloux Agro-Bio Tech, University of Liège, Avenue de la Faculté d'Agronomie 8, \\ 5030 Gembloux, Belgium \\ ${ }^{2}$ Belgian Institute for Space Aeronomy, Ringlaan-3-Avenue Circulaire, 1180 Brussels, Belgium \\ ${ }^{3}$ Research Group Environmental Organic Chemistry and Technology, Faculty of Bioscience Engineering, Ghent University, \\ Coupure links 653, 9000 Gent, Belgium \\ ${ }^{4}$ Laboratory of Plant Ecology, Faculty of Bioscience Engineering, Ghent University, Coupure links 653, 9000 Gent, Belgium
}

Correspondence to: B. Heinesch (bernard.heinesch@ulg.ac.be)

Received: 5 August 2011 - Published in Atmos. Chem. Phys. Discuss.: 25 August 2011

Revised: 8 December 2011 - Accepted: 23 December 2011 - Published: 11 January 2012

\begin{abstract}
Methanol exchanges over a mixed temperate forest in the Belgian Ardennes were measured for more than one vegetation season using disjunct eddy-covariance by a mass scanning technique and Proton Transfer Reaction Mass Spectrometry (PTR-MS). Half-hourly methanol fluxes were measured in the range of $-0.6 \mu \mathrm{g} \mathrm{m}^{-2} \mathrm{~s}^{-1}$ to $0.6 \mu \mathrm{g} \mathrm{m}^{-2} \mathrm{~s}^{-1}$, and net daily methanol fluxes were generally negative in summer and autumn and positive in spring. On average, the negative fluxes dominated (i.e. the site behaved as a net sink), in contrast to what had been found in previous studies.

An original model describing the adsorption/desorption of methanol in water films present in the forest ecosystem and the methanol degradation process was developed. Its calibration, based on field measurements, predicted a mean methanol degradation rate of $-0.0074 \mu \mathrm{g} \mathrm{m}^{-2} \mathrm{~s}^{-1}$ and a half lifetime for methanol in water films of $57.4 \mathrm{~h}$. Biogenic emissions dominated the exchange only in spring, with a standard emission factor of $0.76 \mu \mathrm{g} \mathrm{m}^{-2} \mathrm{~s}^{-1}$.

The great ability of the model to reproduce the long-term evolution, as well as the diurnal variation of the fluxes, suggests that the adsorption/desorption and degradation processes play an important role in the global methanol budget. This result underlines the need to conduct long-term measurements in order to accurately capture these processes and to better estimate methanol fluxes at the ecosystem scale.
\end{abstract}

\section{Introduction}

Methanol is the second most abundant organic gas in the atmosphere after methane (Jacob et al., 2005; Singh et al., 2001). Its mixing ratio can easily exceed $10 \mathrm{ppbv}$ above forests during the growing season (Karl et al., 2003; Schade and Goldstein, 2001, 2006). Methanol plays a minor but non-negligible role in atmospheric chemistry (Harley et al., 2007; Jacob et al., 2005). It reduces atmospheric oxidation capacity due to its reactions with hydroxyl radicals $(\mathrm{OH})$, producing formaldehyde $\left(\mathrm{CH}_{2} \mathrm{O}\right)$ and hydroperoxyl radicals $\left(\mathrm{HO}_{2}\right)$, thereby increasing the tropospheric ozone concentration (Tie et al., 2003). The chemical atmospheric lifetime of methanol is from 5 to 12 days (Atkinson, 2000; Galbally and Kirstine, 2002; Jacob et al., 2005; Millet et al., 2008; Tie et al., 2003). Several modelling studies (Galbally and Kirstine, 2002; Heikes et al., 2002; Jacob et al., 2005; Singh et al., 2000; Stavrakou et al., 2011; Tie et al., 2003) have focused on the global methanol budget. These studies show that the principal methanol source in the atmosphere is vegetation (60-80\%) and that the major sinks are the reaction with $\mathrm{OH}$ in gas-phase (40-70\%) and dry deposition on land $(20-30 \%)$. These modelling efforts, however, remain characterized by huge uncertainties. Estimations of global emission by plants vary between 75 (Singh et al., 2000) and 280 (Heikes et al., 2002) $\mathrm{Tg} \mathrm{yr}^{-1}$ and estimations of global sinks through $\mathrm{OH}$ reaction and dry deposition vary between 133 (Galbally and Kirstine, 2002) and 234 (Tie et al., 2003) $\mathrm{Tg}_{\mathrm{yr}}-1$. These uncertainties are due mainly to a lack of 
available measurements, which are typically limited in terms of temporal and spatial resolution, leading to limited knowledge about emission and deposition mechanisms. To date, about 15 studies (see a partial review of them in Seco et al., 2007) have measured and quantified methanol exchange above a variety of ecosystems (mainly forests and grasslands) using a variety of techniques (relaxed eddy accumulation and disjunct eddy-covariance). These studies usually cover only a small part of the vegetation season, centred on time periods when biogenic emissions are thought to be important, and are still too limited in terms of the variety of ecosystems that are potential methanol emitters. Among these techniques, disjunct eddy-covariance is the most suitable for long-term monitoring of the ecosystem exchange in real-undisturbed conditions (Rinne et al., 2001). It has been used in several methanol studies (Bamberger et al., 2010; Brunner et al., 2007; Custer and Schade, 2007; Holst et al., 2010; Karl et al., 2001, 2002, 2003, 2004, 2005; Langford et al., 2010; Spirig et al., 2005), but none of them (at the exception of Hörtnagl et al., 2011 above a temperate mountain grassland) proposed a year-round follow-up of the exchange. In addition, although methanol dry deposition has been observed occasionally or more regularly in some studies (Custer and Schade, 2007; Holst et al., 2010; Karl et al., 2004, 2005; Langford et al., 2010; Schade et al., 2010; Spirig et al., 2005), very few of these studies paid detailed attention to the underlying mechanisms.

In this study, we present long-term ecosystem-scale measurements of methanol fluxes exchanged between a heterogeneous temperate forest and the atmosphere, obtained using the disjunct eddy-covariance by mass scanning. Our dataset covers more than one vegetation period (winter is not included), with a total composite coverage of 10 months. The main result of the study is that, on a long-term scale, the site behaved as a methanol sink in contrast to what has been found at other sites. In order to better understand these results, abiotic and biotic drivers of the methanol emissions/depositions were disentangled. An original model was developed in order to estimate the respective contributions to the net flux of the methanol adsorption/desorption in water films present in the ecosystem and of methanol degradation. Model residuals were then used to isolate biogenic emissions and to identify their driving variables.

\section{Material and methods}

\subsection{Measurement site}

The experimental site is a forest ecosystem located at Vielsalm in the Belgian Ardennes forest $\left(50^{\circ} 18^{\prime} 18.20^{\prime \prime} \mathrm{N}\right.$, $5^{\circ} 59^{\prime} 53.15^{\prime \prime} \mathrm{E}$; altitude $450 \mathrm{~m}$ ). Its topography is smoothly sloping $(3 \%)$ in a north-westerly direction. The climate is temperate maritime. The soil is $50-100 \mathrm{~cm}$ deep and is classified as a dystric cambisol. The vegetation in the tower flux footprint is a mixture of: coniferous species, mainly Douglas fir (Pseudotsuga menziesii [Mirb.] Franco) about $40 \mathrm{~m}$ high, Norway spruce (Picea abies [L.] Karst.) about $32 \mathrm{~m}$ high, Silver fir (Abies alba Miller) about $32 \mathrm{~m}$ high; and deciduous species, mainly beeches (Fagus sylvatica L.) about $28 \mathrm{~m}$ high. A more detailed description of this site is given by Aubinet et al. (2001, 2002) and Laitat et al. (1999).

\subsection{Instrumentation and BVOC sampling}

An ultrasonic anemometer (model SOLENT 1012 R2, Gill Instruments Ltd, Lymington, UK) was placed at the top of a tower at a height of $52 \mathrm{~m}$, and it continuously measured the three wind velocity components at a sampling frequency of $20.8 \mathrm{~Hz}$. Ambient air was continuously sampled close to the sonic anemometer through a main sampling line (PFA tubing: Fluortechnik-Wolf) $60 \mathrm{~m}$ long and $6.4 \mathrm{~mm}$ inner diameter, with a flow rate of $9 \mathrm{STP} 1 \mathrm{~min}^{-1}$ (Standard Pressure and Temperature conditions corresponded to $1013.25 \mathrm{hPa}$ and $273.15 \mathrm{~K})$. The sampling line was wrapped with two heating cables $\left(20 \mathrm{~W} \mathrm{~m}^{-1}\right)$ and three thermistors were placed along the line to monitor the heating. The output of the thermistors showed that the line was on average $12^{\circ} \mathrm{C}$ above ambient temperature. Part of this air flow $\left(0.1 \mathrm{STP} 1 \mathrm{~min}^{-1}\right)$ was drawn into a gas analyser through a $1.2 \mathrm{~m}$ long heated capillary inlet line $(333 \mathrm{~K})$ with an inner diameter of $1 \mathrm{~mm}$. The data streams coming from the two instruments were logged on a single computer in order to optimise synchronization.

Measurements of relevant meteorological variables were performed at a sampling frequency of $0.04 \mathrm{~Hz}$ and averaged over half an hour, including total and diffuse fraction of photosynthetically active radiation: PPFD (Sunshine sensor type BF3, Delta-T Devices Ltd, Cambridge, UK), net radiation: $R_{\text {net }}($ Q7.1, REBS, Seattle, WA, USA), air temperature and humidity (RHT2, Delta-T Devices Ltd, Cambridge, UK) at a height of $50 \mathrm{~m}$, soil moisture content (ThetaProbe, Delta-T Devices Ltd, Cambridge, UK) at a depth of $20 \mathrm{~cm}$, and precipitation and atmospheric pressure (MPX4115A, Motorola, Phoenix, USA). A global Vegetation Area Index (VAI) was deduced from PPFD measurements above and below the canopy, as described by Aubinet et al. (2002).

VOC concentrations were measured by a conventional hs-PTR-MS (Ionicon Analytick GmbH, Innsbruck, Austria) equipped with a quadrupole mass spectrometer. Detailed descriptions of the PTR-MS technique are given by Lindinger et al. (1998), de Gouw et al. (2007) and Ammann (2004). The PTR-MS was operated at a drift tube pressure of $2.1 \mathrm{hPa}$, a drift tube temperature of $333 \mathrm{~K}$ and a drift voltage of $600 \mathrm{~V}$, resulting in an $E / N$ of 143 Townsend $\left(1 \mathrm{Td}=10^{-17} \mathrm{~V} \mathrm{~cm}^{2}\right)$, where $E$ is the electric field and $N$ the ambient air number density in the flow/drift tube. The ion signals were measured in a cyclic way (which produces a disjunct time series for each mass) at mass to charge ratio $\mathrm{m} / \mathrm{z}, 21$ (primary hydronium ions: $\mathrm{H}_{3}^{18} \mathrm{O}^{+}$), $\mathrm{m} / \mathrm{z} 33$ (protonated methanol), $\mathrm{m} / \mathrm{z} 39$ (water cluster ion), $m / z, 45$ (protonated acetaldehyde), $m / z, 59$ 
(protonated acetone), $\mathrm{m} / \mathrm{z} 69$ (protonated isoprene), $\mathrm{m} / \mathrm{z} 71$ (protonated methyl vinyl ketone and methacrolein), $\mathrm{m} / \mathrm{z} 81$ (fragment of protonated monoterpenes), $\mathrm{m} / \mathrm{z} 87$ (protonated methylbutenol and possibly others) and $\mathrm{m} / \mathrm{z} 137$ (protonated monoterpenes). In 2010, $\mathrm{m} / \mathrm{z} 47$ (protonated formic acid) and $\mathrm{m} / \mathrm{z} 61$ (protonated acetic acid) were added. The dwell time for each mass was $0.2 \mathrm{~s}$, ending in a $2 \mathrm{~s}$ measurement cycle length. During the measurements, the instrumental background was determined every $4 \mathrm{~h}$ by sampling BVOC-free air, obtained by sending ambient air through a heated catalytic converter for $15 \mathrm{~min}$ (the last $8 \mathrm{~min}$ being used for the calculation of the mean background values). The background measurements for $\mathrm{m} / \mathrm{z} 33$ (protonated methanol) may be somewhat more complicated than the background measurements for the other compounds. Indeed, the measured background signal at $\mathrm{m} / \mathrm{z} 33$ consists of the real instrumental background at $m / z, 33$ and the oxygen isotopes $\left({ }^{16} \mathrm{O}^{17} \mathrm{O}^{+}\right)$ (Spirig et al. 2005). Background measurement was generated from ambient air just at the bottom of the tower, which can be somewhat more humid than the air from the top of the tower, which can have a small influence on the strength of the $\mathrm{O}_{2}^{+}$signal $(\mathrm{m} / \mathrm{z}, 32)$ and its second isotope. Once a month of 2010, we have estimated that the error caused by this effect on your $\mathrm{m} / z 33$ measurements was less than $3 \%$.

The sensitivity of the instrument was calibrated for the main target compounds (isoprene, sum of monoterpenes, methanol, acetone and acetaldehyde) every two or three days using a gravimetrically prepared mixture of these gases in $\mathrm{N}_{2}$ (Apel-Riemer Environmental, Denver, CO, USA) that contained approximately $500 \mathrm{ppbv}$ isoprene, $\alpha$-pinene and sabinene and about 1 ppmv methanol, acetaldehyde and acetone, with an accuracy of $5 \%$. The compounds were further diluted (2-12 ppbv range) using a dynamic dilution system. More details can be found in Laffineur et al. (2011).

\subsection{Disjunct eddy-covariance}

The technique used to measure ecosystem BVOC fluxes is disjunct eddy-covariance by mass scanning (Karl et al., 2002; Rinne et al., 2001). The flux $\left(F_{\text {VOC }}\right)$ is determined by the covariance of the discrete function between the time series of vertical wind velocity $w(t)$ and VOC concentration $C_{\mathrm{VOC}}(t)$ over an averaging period of $30 \mathrm{~min}(T)$ :

$F_{\mathrm{VOC}}=\frac{1}{N} \sum_{i=1}^{N} w^{\prime}\left(t_{i}-t_{\mathrm{lag}}\right) \cdot C_{\mathrm{VOC}}^{\prime}\left(t_{i}\right)$

with $w^{\prime}, C_{\mathrm{VOC}}^{\prime}$, the instantaneous deviations from the mean value of $w$ and $C_{\mathrm{VOC}}$ respectively, $N$ the number of disjunct PTR-MS samples (790 in 2009 and 605 in 2010 due to the addition of two other masses in the measurement cycle) during $T$ and $t_{\text {lag }}$ the lag time between $w$ and $C_{\mathrm{VOC}}$ induced by the distance between inlet and PTR-MS. The time lag was computed for each half-hour by shifting one-time series relative to the other until the absolute maximum covariance between the two-time series was determined. We used the filled-time series as proposed by Spirig et al. (2005) to determine the time lag (but not to compute fluxes). This approach allowed an easier time lag determination and is similar to the averaging approach proposed by Taipale et al. (2010). The mean time lag found using this method was $14.8 \mathrm{~s}$ for methanol and others BVOCs, close to $12.9 \mathrm{~s}$, the theoretical value computed from the flow rate and the inlet line volume. This experimental mean time lag was used as the default value when we did not found a maximum in the covariance function inside the $[10 \mathrm{~s}, 18 \mathrm{~s}]$ time window. Methanol fluxes were computed using block average over $30 \mathrm{~min}$ periods, and 2-D rotation was applied. Stationarity test (Foken and Wichura, 1996) was not applied in this study as in Brunner et al. (2007), because fluxes would hardly pass the test (more than $40 \%$ of data would have been rejected) and because this filtering did not increase the quality of our methanol data. A filter linked to anthropogenic influence (Sect. 2.4) and a stability filter (Sect. 4.3.1) were applied. Over the course of the two measurements campaigns 10138 half-hourly fluxes for methanol were recorded, of which 5481 passed all filtering criteria.

High frequency losses due mainly to the damping of concentration fluctuations in the sampling line were corrected experimentally following the method reported by Aubinet et al. (2001) using a transfer function determined by a comparison of the sensible heat flux co-spectra and the $m / z, 69$ flux co-spectra. From this unique transfer function, a correction factor was deduced which was applied to the BVOC fluxes. For example, for a wind speed of $3 \mathrm{~m} \mathrm{~s}^{-1}$ (mean value of our dataset), we obtained a correction factor of 1.49. More details on the flux computation methodology are given by Laffineur et al. (2011).

\subsection{Data filtering}

In the $230-270^{\circ}$ wind direction sector, which was also the main wind direction, methanol fluxes could be contaminated by the activities of a wood panel factory, $3 \mathrm{~km}$ from the tower. Wood panel production is known to emit high levels of monoterpenes and methanol (Nicholson, 2003). Although not located inside the main day flux footprint, defined as the $90 \%$ level contribution to the total flux (footprint analyses were performed with a two-dimensional analytical footprint software tool proposed by Neftel et al. (2008) in line with the Kormann-Meixner footprint model, Kormann and Meixner, 2001), this source was probably so important compared with forested ecosystem sources that it influenced our measurements. Flux measurements spoiled by anthropogenic emissions were therefore rejected, using a filtering criterion based on the variance of the monoterpene mixing ratio. Indeed, it is easier to define a threshold on the monoterpenes variance than on the methanol variance to exclude precisely the data affected strongly by factory emissions $(27 \%$ of data 2009-2010 was rejected). Figure 1 shows the effect of 


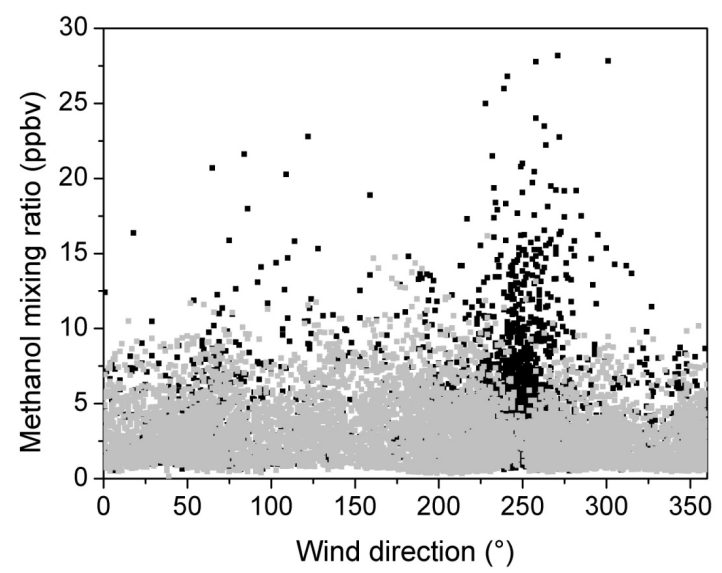

Fig. 1. The black points represent the methanol flux data (20092010) deleted by the monoterpenes variance filtering. The light grey points represent the data that succeed the test.

the monoterpenes variance filtering on the methanol mixing ratio. The monoterpenes variance seems to be a sufficiently robust criterion to exclude methanol data affected by the factory. The filtering suppresses also data points outside the factory direction but in a small number of cases in comparison with the number of data point that succeed the test. This procedure was described in detail by Laffineur et al. (2011).

In contrast with $\mathrm{CO}_{2}$ fluxes (Aubinet et al., 1999), $u^{*}$ filtering was not applied here. The methanol flux is not controlled by a continuous production process (like respiration in the case of $\mathrm{CO}_{2}$ ) that works independently of the presence or absence of turbulent transport. The dependence of the methanol flux on turbulence (see Sect. 4.2) corresponds here to a real process (not a measurement artefact), so that any data filtering with a criterion based on turbulence could lead to flux overestimation (Aubinet et al., 2012).

\section{Methanol adsorption/desorption model}

The empirical adsorption/desorption model is represented by the electrical analog scheme presented in Fig. 2. Net methanol flux exchange by the ecosystem with the atmosphere is characterized by $F_{1}\left[\mu \mathrm{g} \mathrm{m}^{-2} \mathrm{~s}^{-1}\right.$ ]. This flux consists of two components: the first one $\left(F_{3}\right)$ corresponds to adsorption/desorption in water films present in the ecosystem; and the second one $\left(F_{2}\right)$ corresponds to methanol degradation in aqueous-phase, possibly by methylotrophic organisms. This sink was postulated to deal with the negative methanol budget on a long-term time scale (see Sect. 4.3.2).

The net flux with the atmosphere is written as:

$F_{1}=\frac{1}{R_{\mathrm{t}}}\left(M_{\mathrm{aw}}-M_{\mathrm{aa}}\right)$,

where $M_{\text {aw }}\left[\mu \mathrm{g} \mathrm{m}^{-3}\right]$ and $M_{\text {aa }}\left[\mu \mathrm{g} \mathrm{m}^{-3}\right]$ represent the methanol concentration in the air at the water film surface

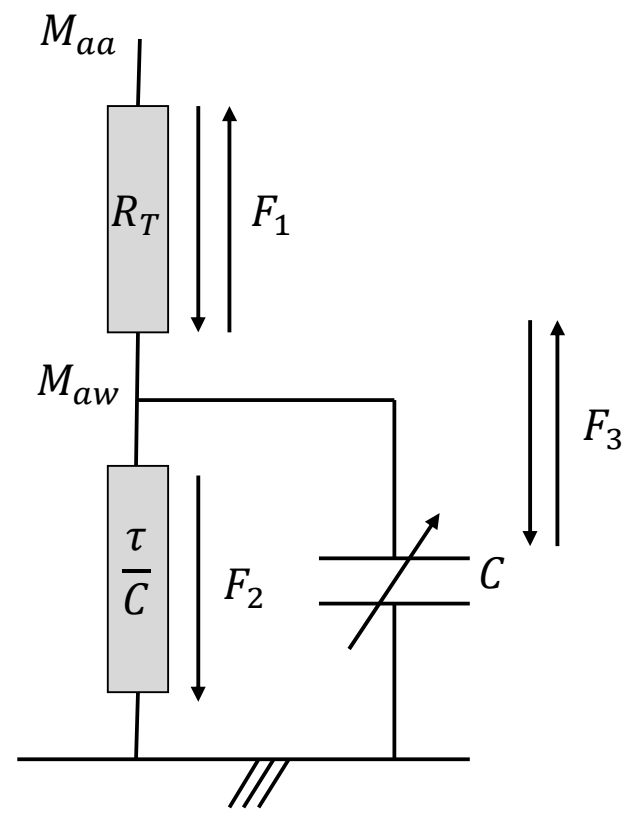

Fig. 2. Electrical analogy for methanol adsorption/desorption/degradation processes. $\quad F_{1}$ represents the net methanol flux exchange, $F_{3}$ represents the adsorption/desorption of methanol in water films (represented by the capacity: $C$ ), $F_{2}$ represents the methanol degradation (represented by the resistance: $\tau / C), M_{\mathrm{aw}}$ and $M_{\mathrm{aa}}$ represent the methanol concentration in the air at the water film surface and in the atmosphere, respectively, and $R_{\mathrm{t}}$ represents the gas-phase resistance to the methanol transfer in the surface boundary layer.

and in the atmosphere, respectively, and $R_{\mathrm{t}}\left[\mathrm{s} \mathrm{m}^{-1}\right]$ represents the gas-phase resistance to the methanol transfer in the surface boundary layer. Sign convention is that a positive flux is directed towards to the atmosphere and a negative flux towards the surface. Considering that molecular diffusion transport is negligible compared to turbulent transport, $R_{\mathrm{t}}$ might be approximated by the aerodynamic resistance of in-canopy air space (Mihailovic et al., 2009; Pul and Jacobs, 1994) in a very straightforward way:

$R_{\mathrm{t}}=\frac{1}{A \cdot u^{*}}$,

where $A$ is an empirical parameter and $u^{*}\left[\mathrm{~m} \mathrm{~s}^{-1}\right]$ is the friction velocity. The aerodynamic resistance above the canopy can be considered negligible compared with this resistance.

In this model, we consider that the methanol reservoir in the ecosystem is made of water films present on leaves and wet soil surfaces that can adsorp/desorp methanol. In these conditions, $M_{\mathrm{aw}}$ can be related to the total methanol content in the water film reservoirs of the ecosystem $\left(q\left[\mu \mathrm{g} \mathrm{m}^{-2}\right]\right)$ by:

$M_{\mathrm{aw}}=\frac{q}{C}$, 
where $C\left[\mathrm{~m}^{3} \mathrm{~m}^{-2}\right]$ represents the capacity of the water films to store methanol as suggested by Sutton et al. (1998) in the context of ammonia exchange. This constant depends on Henry's law constant, $K_{H}$ [dimensionless (water/air partition ratio)], and on the free water present in the ecosystem. The dimensionless Henry's law constant of methanol is given by (Warneck, 2006):

$K_{H}=\frac{1000 \cdot R \cdot 298 \cdot 15\left[e^{-12.46} e^{5312.4 / T}\right]}{101325}$,

where $R\left[\mathrm{~J} \mathrm{~mol}^{-1} \mathrm{~K}^{-1}\right]$ is the gas constant and $T[\mathrm{~K}]$ represents the temperature that we have considered to be the air temperature $\left(T_{\mathrm{a}}\right)$.

A complete description of the free water content would require establishing a detailed ecosystem water balance, which is not available here. We therefore approximated it by a function of air humidity as suggested by Van Hove and Adema (1996), Burkhardt and Eiden (1994) and Burkhardt et al. (2009) and the precipitation during the preceding days. Dependence on air humidity (see Sect. 4.3.1) was computed by:

$C=K_{H} \cdot \frac{C_{R}}{\left[1-\exp \left(-\frac{D}{\alpha}\right)\right]}$,

where $D[\mathrm{~Pa}]$ is the water vapour pressure deficit, $\alpha[\mathrm{Pa}]$ is an empirical parameter and $C_{R}[\mathrm{~m}]$ is the component of the capacity that depends on the precipitation $(P[\mathrm{~mm}])$ of the preceding days. Without information on the leaf/soil water balance from precipitation, $C_{R}$ was computed simply by a linear dependence on cumulated precipitation of the 10 preceding days (480 half-hours):

$C_{R}=C_{R 0}+\sum_{i=0}^{480} P_{i}$,

where $C_{R 0}$ is a residual capacity.

Methanol degradation is described by a diffusion flux $\left(F_{2}\right)$ and characterized by a resistance $\tau / C$ :

$F_{2}=-\frac{q}{\tau}$,

where $\tau$ [s] represents a time constant, characteristic of the methanol lifetime in the water films in the absence of adsorption or desorption.

Using Kirchhoff's circuit law, we can write:

$F_{3}=F_{1}-F_{2}=-\frac{d q}{d t}$.

By introducing Eqs. (1-3) and (7) in (8) and approximating the equation by finite differences, we get:

$q_{j}=q_{j-1}-\Delta t\left[A \cdot u^{*} \cdot\left(\frac{q_{j-1}}{C}-M_{\mathrm{aa}}\right)+\frac{q_{j-1}}{\tau}\right]$,

where $\Delta t$ is the integration time, fixed in this study to one half-hour (1800 s) and index $j$ denotes successive time period intervals.
By introducing expression (9) of $q$ into (3) and then into (1), we then get:

$F_{1, j}=A \cdot u^{*} \cdot\left[\frac{q_{j}}{K_{H} \cdot \frac{C_{R 0}+\sum_{i=0}^{480} P_{i}}{\left[1-\exp \left(-\frac{D}{\alpha}\right)\right]}}-M_{\mathrm{aa}}\right]$.

Finally, the complete model given by Eq. (10) depends on four empirical parameters: $A, \tau, C_{R 0}$ and $\alpha$.

\section{Results}

\subsection{Micrometeorological and methanol flux evolutions}

The seasonal evolution of air temperature $\left(T_{\mathrm{a}}\right)$, photosynthetically active radiation (PPFD), water vapour pressure deficit $(D)$, precipitation $(P)$, friction velocity $\left(u^{*}\right)$, methanol ambient mixing ratio and methanol flux is shown in Fig. 3.

Summer and autumn 2009 were characterized by high temperatures (mean temperature in July-August-September $\left.15.7^{\circ} \mathrm{C}\right)$ for the region, except at the end of October $\left(8.4{ }^{\circ} \mathrm{C}\right)$. August and September were relatively dry with cumulated rain close to only $50 \mathrm{~mm}$. The temperature conditions during spring 2010 were normal for the region (mean temperature in April-May-June $10.9^{\circ} \mathrm{C}$ ), except during the first half of May, which followed the bud break of Fagus sylvatica on 1 May and was colder and cloudier than average. The AprilMay-June period was, however, dry, with cumulated rain of only $86 \mathrm{~mm}$. Summer 2010 was also characterized by high temperatures (mean temperature in July-August-September $15.2^{\circ} \mathrm{C}$ ), especially between 7 and 14 July. The highest $D$ ( $>0.8 \mathrm{kPa}$ ) were observed mainly between the end of June and the end of July 2010. In contrast with 2009, August 2010 was very rainy, with cumulated rain of $215 \mathrm{~mm}$. The annual mean temperature (cumulated rain) in the region was $8.5^{\circ} \mathrm{C}(939 \mathrm{~mm})$ and $7.4^{\circ} \mathrm{C}(896 \mathrm{~mm})$ in 2009 and 2010 respectively.

The atmospheric methanol concentration course in the spring and summer periods was similar and varied between 0.8 and $8.7 \mathrm{ppbv}$ (5th centile and 95th centile), with a mean of $3.5 \mathrm{ppbv}$. In autumn, the methanol concentration was close to $2.0 \mathrm{ppbv}$. Methanol fluxes were bi-directional. The highest deposition fluxes were observed in July 2009 and in AugustSeptember 2010 (up to $-0.6 \mu \mathrm{g} \mathrm{m}^{-2} \mathrm{~s}^{-1}$ ), while the highest emissions (up to $0.6 \mu \mathrm{g} \mathrm{m}^{-2} \mathrm{~s}^{-1}$ ) were observed during the second half of May 2010 and the beginning of June 2010. To a lesser extent, emissions were observed during July-August 2009 and during the second half of April 2010 and the end of June 2010.

Figure 4 shows the mean diurnal evolution of the methanol flux in the summer in 2009 and 2010 and in spring 2010. In both cases, the flux was generally positive during the day and negative at night, but in spring the fluxes shifted towards more positive values compared with summer, the net daily 


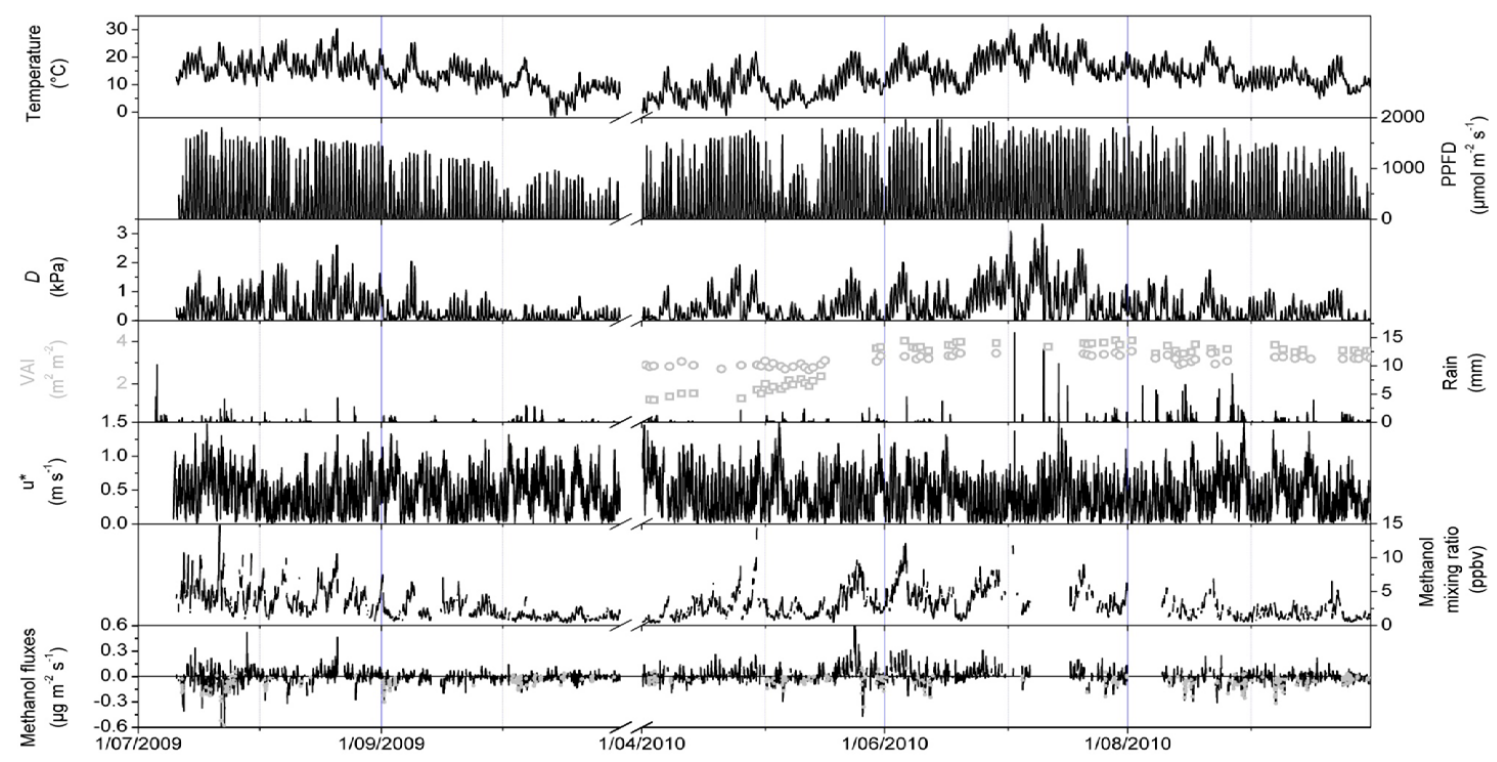

Fig. 3. Temporal evolution of meteorological variables, methanol mixing ratio and methanol flux between 10 July and 31 October 2009 and between 1 April and 30 September 2010: air temperature $\left(T_{\mathrm{a}}\right)$, PPFD, vapour pressure deficit $(D)$, precipitation, vegetation area index (VAI) of beeches $(\square)$ and Douglas $(\bigcirc)$, friction velocity $\left(u^{*}\right)$, ambient methanol mixing ratio and methanol fluxes (the rain events are identified with grey points).

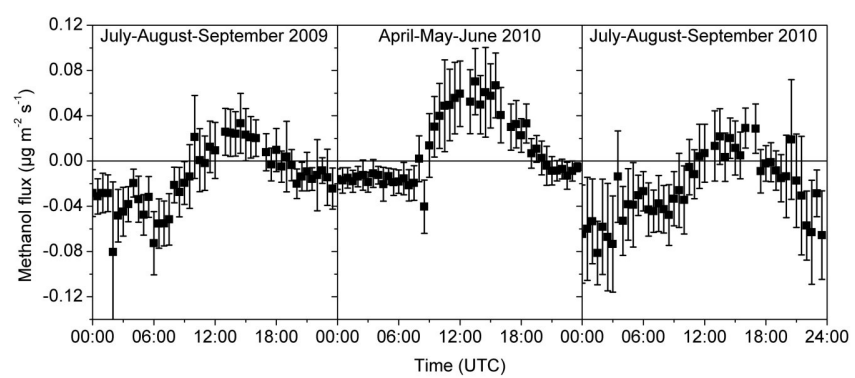

Fig. 4. Mean diurnal evolutions of methanol flux (error bars are $95 \%$ confidence intervals).

flux being roughly twice as large in spring as in summer. As a result, the net daily flux was negative in summer (deposition dominates) and positive in spring (emission dominates). For the whole measurement period, deposition was generally less pronounced in the beginning of the night than at the end.

\subsection{Main drivers of methanol flux}

In order to determine the main drivers of methanol fluxes, their relationships with the main meteorological variables (radiation, air temperature, water vapour pressure deficit, friction velocity, atmospheric methanol concentration) were tested. Only the most relevant relationships are presented here. The clearest response of methanol flux to climatic variables is the one to water vapour pressure deficit (Fig. 5). At low $D$, fluxes are mainly negative, indicating methanol de-

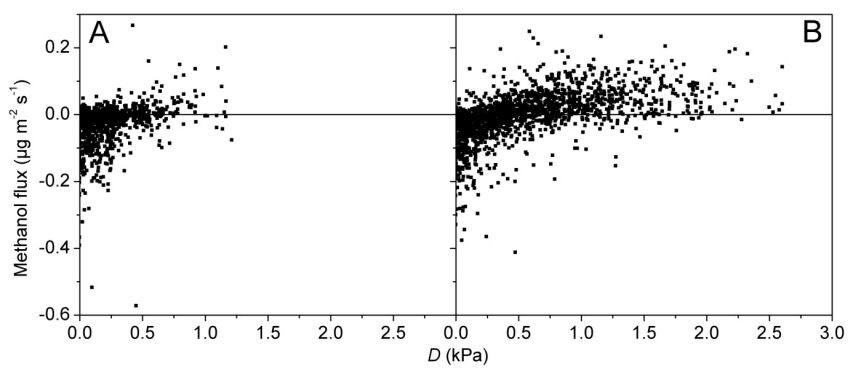

Fig. 5. Vapour pressure deficit $(D)$ dependence of methanol flux in night (A) and day (B) conditions for July-August-September 2009.

position. The flux increases with $D$, and tends towards a positive and constant value above $D=1 \mathrm{kPa}$. The influence of humidity on the methanol exchange can be seen in Fig. 3 where deposition is systematically observed during or following precipitation.

A linear dependence between the ratio of $F$ to $M_{\mathrm{aa}}$ and $u^{*}$ was also found (Fig. 6), only when wet conditions ( $D<0.15 \mathrm{kPa}$ ) were selected (and $R_{\text {net }}>-20 \mathrm{~W} \mathrm{~m}^{-2}$, explanation below). In these wet conditions, $M_{\mathrm{aw}}$ can be close to zero, the ratio $F$ to $M_{\text {aa }}$ thereby representing a deposition velocity (see Sect. 4.3.1 and Foken et al., 2008). Similar relationships were observed for day and night. Slope (parameter $-A$ in the model) and intercept coefficients were equal to $-0.055 \pm 0.004$ and $-0.0018 \pm 0.0022 \mathrm{~m} \mathrm{~s}^{-1}$ (0.36), respectively, for the day and equal to $-0.060 \pm 0.002$ and $-0.0043 \pm 0.0011 \mathrm{~m} \mathrm{~s}^{-1}\left(R^{2}=0.58\right)$, respectively, for the 


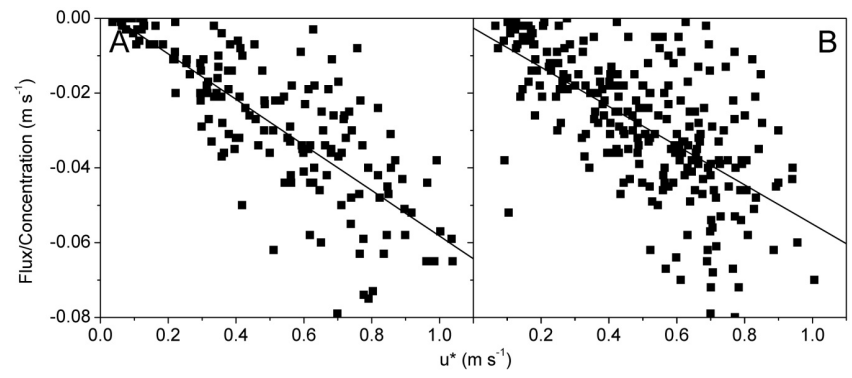

Fig. 6. Relationship between the ratio methanol flux/ambient methanol concentration and the friction velocity $\left(u^{*}\right)$ in night (A) and day (B) conditions for July-August-September 2009, respecting these conditions: flux $<0 \mu \mathrm{g} \mathrm{m}^{-2} \mathrm{~s}^{-1},<0.15 \mathrm{kPa}$ and $>-20 \mathrm{~W} \mathrm{~m}^{-2}$.

night. For the whole measurement period, the mean $u^{*}$ was $0.4 \mathrm{~m} \mathrm{~s}^{-1}$, which corresponds to a deposition velocity of $2.4 \mathrm{~cm} \mathrm{~s}^{-1}$.

The relationship between methanol exchange and temperature appeared to be complex (Fig. 7), with the most important negative fluxes being observed between 10 and $20^{\circ} \mathrm{C}$ and the most important positive fluxes between 15 and $25^{\circ} \mathrm{C}$.

\subsection{Bi-directional methanol flux modelling}

The methanol deposition quantities increased strongly with increasing air humidity, indicating that water on the leaf and/or soil surface plays a major role in the interaction of methanol with leaf and/or soil surfaces. This is due to microscale liquid water films and/or droplets formed on external plant/soil surfaces through condensation of water vapour on the leaf/soil surface or through rain or fog droplets from the atmosphere. The dependence of the deposition velocity on $u^{*}$ (Fig. 6) indicates that turbulent transport is the main resistance driving deposition. The complex response of deposition to air temperature could be due to the interaction between the temperature dependency of methanol solubility (Henry's law) in water and of air saturation deficit.

Our observations therefore strongly suggest that methanol fluxes could be driven by the adsorption/desorption process of methanol in water films that are present in the ecosystem. We have used the model developed in section 3 to prove this hypothesis.

The model has 5 input variables $\left(T_{\mathrm{a}}, u^{*}, M_{\mathrm{aa}}, D\right.$ and $\left.P\right)$ and 4 site-specific parameters $\left(A, \tau, C_{R 0}\right.$ and $\left.P\right)$. In this section, the model will first be calibrated (Sect. 4.3.1) and validated (Sect. 4.3.2) on data sets where the abiotic processes appear dominant (i.e. in summer). The model will then be used (Sect. 4.3.3) to compute the abiotic component in spring. Finally, abiotic flux simulations will be combined with measurements in order to isolate the biogenic contributions to the fluxes and these fluxes will be analysed more deeply. Calibration will be performed on summer 2009 data (July to September) and validation on summer 2010 data.

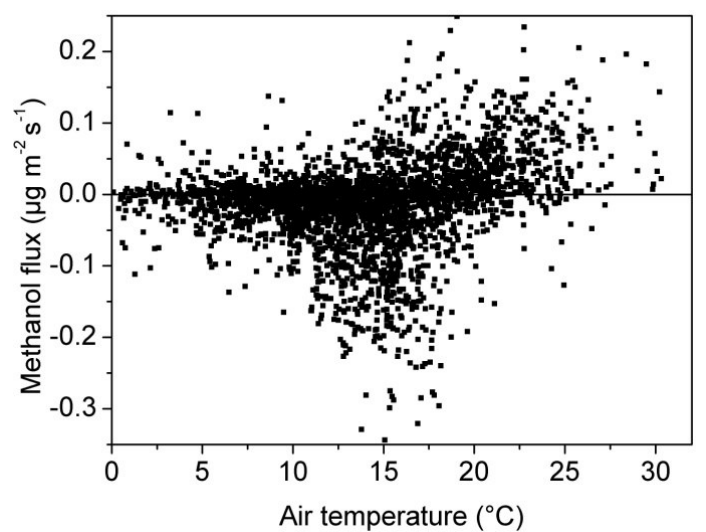

Fig. 7. Methanol flux in relation with the air temperature for JulyAugust-September 2009.

\subsubsection{Model calibration (summer 2009)}

The calibration was performed in three steps. First, for parameter $A$, the value found in Sect. 4.2 (Fig. 6) above was retained, selecting night conditions when stomata are closed to limit the possible effect of biogenic emissions on the parameter $A$. Second, $\alpha$ was also deduced from the results of Sect. 4.2 (Fig. 5). A function of the type:

$f(\alpha)=\Psi \cdot\left[1-\exp \left(-\frac{D}{\alpha}\right)\right]$

was adjusted on the relationship between $M_{\mathrm{aw}}, u^{*}$ and $D$ (Fig. 8), $\Psi=\frac{q}{C_{R}}$ being a free parameter (corresponding to a residual concentration) and $M_{\text {aw }}$ being deduced from Eq. (1) by using our measurements $\left(M_{\mathrm{aa}}, u^{*}\right.$ and $\left.F_{\downarrow 1}=F_{\downarrow \text { measured }}\right)$. We obtained $\alpha=588 \pm 69 \mathrm{~Pa}\left(R^{2}=0.44\right)$.

Third, the last two parameters $\left(\tau, C_{R 0}\right)$ were estimated by minimising the square root differences between modelled and measured cumulated fluxes. This provided $C_{R 0}=0.176$ $\mathrm{m}$ and $\tau=82.8 \mathrm{~h}$, the latter corresponding to a half lifetime of $57.4 \mathrm{~h}$. If $C_{R 0}$ is interpreted as the minimum total height of water films in the ecosystem, its value may look unrealistically high. This is probably because we use air temperature for the computation of the Henry's law constant instead of the temperature of the water films at the soil surface. This latter temperature is not available, but is usually lower than the air temperature, leading to a systematic underestimation of $K_{H}$ compensated by a high fitted $C_{R 0}$.

In the above calibration and in the subsequent validation phase, we rejected data with net radiation below $-20 \mathrm{~W} \mathrm{~m}^{-2}$ because in these atmospheric conditions (11\% of the dataset after the anthropogenic filtering) the oversimplified parameterisation chosen for $R_{\mathrm{t}}$ in Eq. (2) underestimates the incanopy aerodynamic resistance (Pul and Jacobs, 1994). In summer, the comparison between measured mean diurnal evolution of methanol fluxes without (Fig. 4) and with $R_{\text {net }}$ filtering (Fig. 9a) shows that, under stable atmospheric 


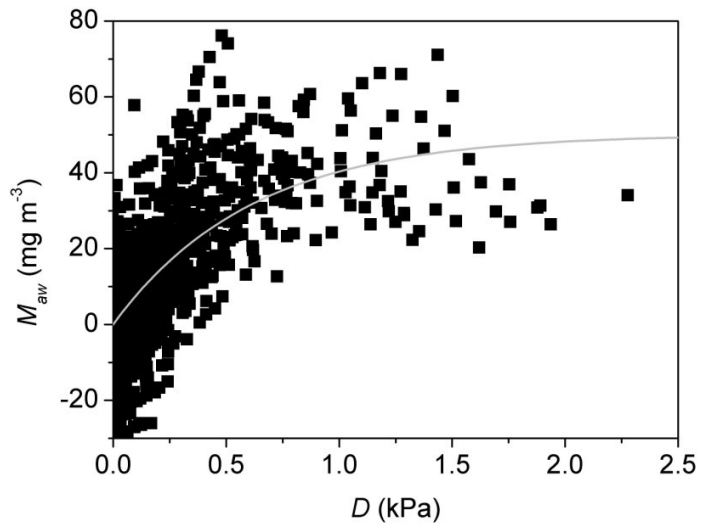

Fig. 8. Relationship between the concentration of methanol $\left(M_{\mathrm{aw}}\right)$ in the water films and the vapour pressure deficit $(D)$ for JulyAugust-September 2009. The negative value is due to the modeled uncertainty of $M_{\mathrm{aw}}\left( \pm 20 \mathrm{mg} \mathrm{m}^{3}\right)$.

conditions, the turbulent exchange is dampened, therefore limiting the exchange. Without $R_{\text {net }}$ filtering, the model would have predicted unrealistically strong deposition (result not shown) during these events.

In the case of long data gaps (more than 10 days), the model lacks information on the temporal evolution of total methanol content in the water films. Several days are needed after the measurement recovery to allow reliable modelling. Such data gaps did, for instance, occur in 2010, the first one in July and the second at the beginning of August. In these cases, we discarded the results obtained less than 4 days after the measurement recovery.

After calibration, the model was able to reproduce the intra-day (Fig. 9a) as well as the long-term (Fig. 9b) flux dynamics. The frequency distribution of the differences between measurements and simulations (Fig. 9c) is characterized by a mean and a median close to zero and by a standard deviation of $0.065 \mu \mathrm{g} \mathrm{m}^{-2} \mathrm{~s}^{-1}$. This standard deviation probably originates from the random errors introduced by the DEC method (Hörtnagl et al., 2010) and by the spatial distribution of sources/sinks that can affect measurements, especially at low wind speed (Richardson et al., 2006). The effect of these random errors was limited in time by performing the model calibration on cumulated fluxes instead of using individual half-hours. The cumulated flux shows a linear decrease with time (Fig. 9b). This decrease is due to methanol degradation that affects the long-term evolution of the modelled flux. The slope of this longterm evolution, representing the mean degradation methanol flux, is $-7.42 \times 10^{-3} \mu \mathrm{g} \mathrm{m}^{-2} \mathrm{~s}^{-1}$. The fluctuations of the cumulated flux around this linear decrease are due to adsorption/desorption mechanisms that, unlike degradation, are short-term effects.
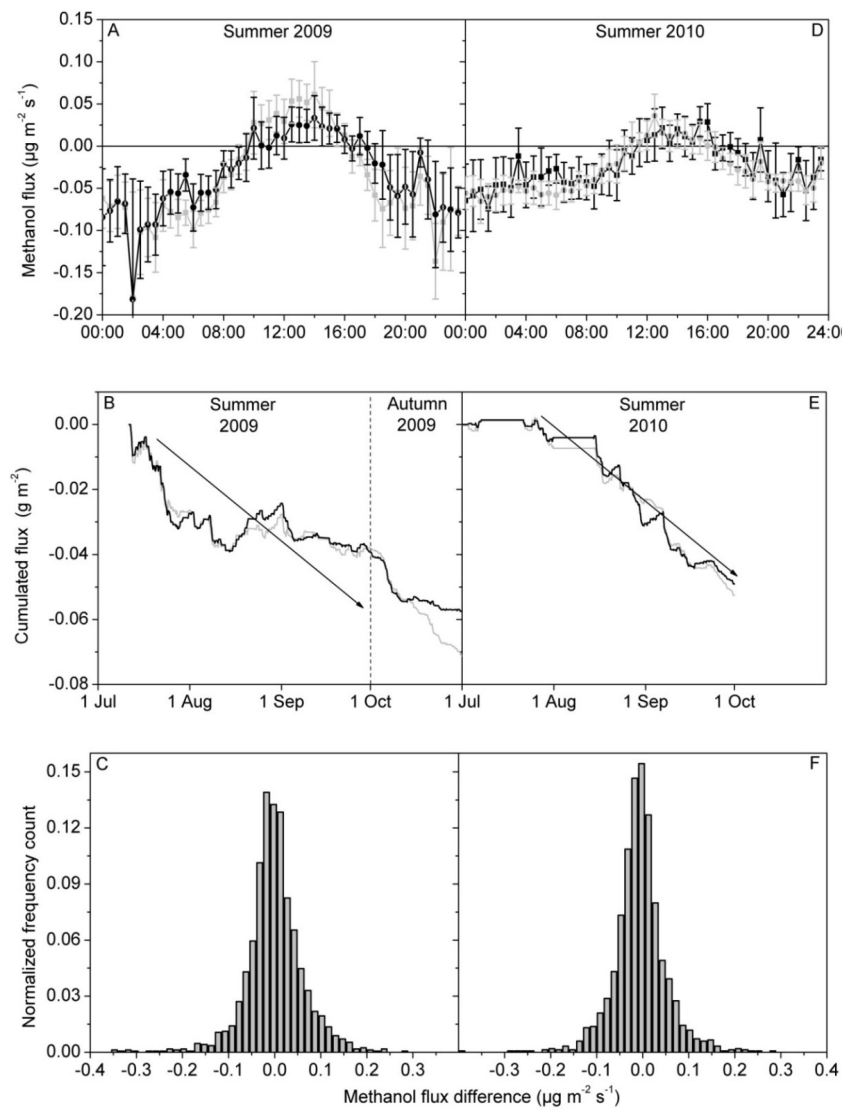

Fig. 9. Mean diurnal flux evolution of modelled (grey line) and measured (black line) methanol flux for the summer 2009 (A) and for the summer $2010(D)$ with $R_{\text {net }}>-20 \mathrm{~W} \mathrm{~m}^{-2}$ (error bars are $95 \%$ confidence intervals), temporal evolution of cumulated measured (black line) and modelled (grey line) methanol flux for the summer 2009 (B) and the summer 2010 (E), distribution of the difference between the measured and modelled methanol flux for the summer 2009 (C) and the summer 2010 (F).

\subsubsection{Model validation (summer 2010)}

Once calibrated with the summer 2009 data, the model reproduced faithfully the observed mean diurnal flux evolution in summer 2010 (Fig. 9d). Measured and modelled cumulated fluxes were also in good agreement (Fig. 9e) and were characterized by a linear decrease similar to that in the calibration phase. In the period from 28 August to 5 September, the model first under-estimated and later over-estimated the depositions. At the beginning of this period, heavy rains occurred and the effect of this is probably poorly represented by the model through Eq. (6) on a short-time scale ( $<10$ days). The frequency distribution of the deviation measurementsmodel (Fig. 9f) is characterized by a mean and a median close to zero and by a standard deviation of $0.057 \mu \mathrm{g} \mathrm{m}^{-2} \mathrm{~s}^{-1}$.

Other divergences were observed in autumn 2009, from 15 October onwards, and also in April 2010 (data not shown), during which the model over-estimated the deposition. One 


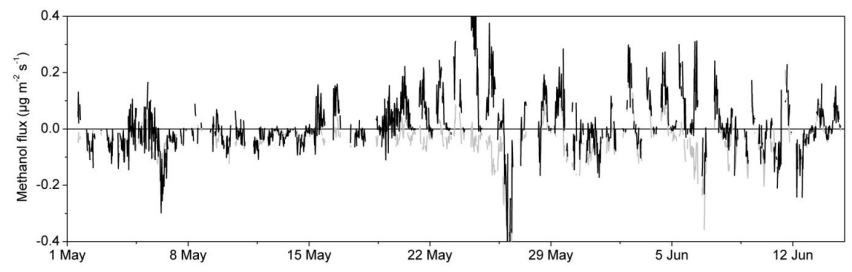

Fig. 10. Temporal evolution of measured (black line) and modeled (grey line) methanol flux between 1 May and 15 June 2010.

reason could be that during both these periods the deciduous trees are leafless, while the model had been parameterised (Eq. 5) on the basis of measurements taken during the fullleaf period. This could lead to an overestimation of the water film capacities during these periods.

\subsubsection{Flux partitioning during transitional phenological phases (spring 2010)}

The model was then applied to spring (May 2010, Fig. 10). As the model computes only the abiotic contribution to the fluxes and the methanol degradation, its residuals (measurement minus modelling) during this period should therefore represent the biogenic emissions. Time evolutions of the residuals and their driving variables have been investigated.

The model residuals during the day become increasingly significant from 20 to 27 May, reaching a maximum value of $0.6 \mu \mathrm{g} \mathrm{m}^{-2} \mathrm{~s}^{-1}$. During this period, when leaves are almost at their full development stage (see VAI, Fig. 3), the model residuals cannot be explained by an overestimation of the water film capacities as suggested for the divergence observed in autumn. Indeed, a possible increase in foliar surface should instead reduce these residuals.

As the biogenic fluxes are known to respond mainly to temperature (Custer and Schade, 2007; Filella et al., 2007; Folkers et al., 2008; Harley et al., 2007) and to PPFD (Brunner et al., 2007; Harley et al., 2007), we investigated the relationships of the model residuals to these two variables. The results are presented in Fig. 11.

Residuals increase with temperature (Fig. 11a) and can be fitted using an exponential relation:

$F_{\text {Methanol }}=\mathrm{SEF}_{30{ }^{\circ} \mathrm{C}} \cdot \exp \left(\beta \cdot\left(T_{\mathrm{a}}-303.15\right)\right)$

where $\mathrm{SEF}_{30}{ }^{\circ} \mathrm{C}$, the standard emission factor at $30^{\circ} \mathrm{C}$ was found to be $0.76 \pm 0.11 \mu \mathrm{g} \mathrm{m}^{-2} \mathrm{~s}^{-1}$ and $\beta$, the temperature dependence parameter, $0.12 \pm 0.01{ }^{\circ} \mathrm{C}^{-1}\left(R^{2}=0.38\right)$.

On the other hand, no obvious relationship (slope coefficient not significantly different from zero, $p=0.1$ ) between the model residuals standardized with air temperature and PPFD was found (Fig. 11b).
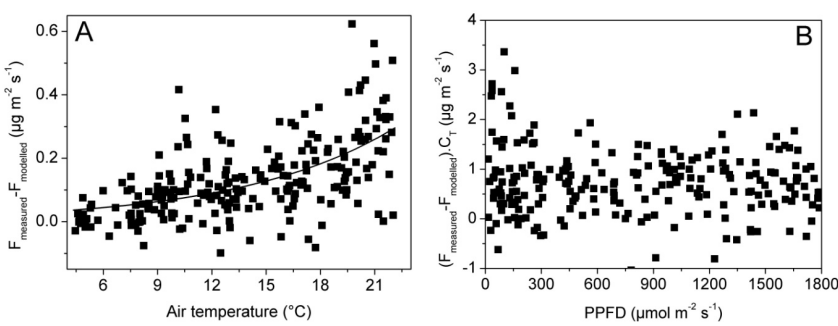

Fig. 11. Relation between the difference of measured/modelled methanol flux and the air temperature (A), relation between the difference of measured/modelled methanol flux standardised at $30^{\circ} \mathrm{C}$ and the PPFD (B) between 15 and 27 May 2010.

\section{Discussion}

\subsection{Comparison with previous flux studies at the ecosystem scale}

This study reports a temperate forest behaving as a net methanol sink $\left(-0.057 \pm 0.012 \mathrm{mg} \mathrm{m}^{-2} \mathrm{~h}^{-1}\right)$ over a 7 -month period (April 2010 to September 2010) and, given the fact that net emissions are not expected during winter, most probably as a sink on an annual basis. This result contradicts most studies published on methanol exchange by forests to date (Karl et al., 2004, 2005; Schade et al., 2010; Spirig et al., 2005), which reported generally positive fluxes and a positive net budget during their measurement periods. Methanol deposition was observed only occasionally in these studies, with a maximum deposition up to $0.15 \mu \mathrm{g} \mathrm{m}^{-2} \mathrm{~s}^{-1}$ for Spirig et al. (2005) over a temperate forest, still four times lower than our maximum deposition. The sole negative net budget over two measurement periods (April-May 2008: $-0.02 \pm 0.02 \mathrm{mg} \mathrm{m}^{-2} \mathrm{~h}^{-1}$ and June-July 2008: $-0.04 \pm 0.02 \mathrm{mg} \mathrm{m}^{-2} \mathrm{~h}^{-1}$ ) was observed by Langford et al. (2010) above a tropical rainforest.

One of the main reasons for these differences is probably that most of these studies were conducted over short periods corresponding with sunny weather conditions and vegetation development, during which biogenic emission dominated. If our study had been limited to spring, it would also have reported such a positive methanol net budget with occasional depositions. The detection of the alternation between day emission and night deposition and of the long-term methanol degradation was possible only because of long-term measurements performed after the single production period.

MEGANv2.1, the state-of the-art empirical upscaling emission algorithm (Stavrakou et al., 2011), is parameterised using emission factors and deposition velocities derived from a compilation of the above-mentioned ecosystem-scale studies. The proposed standard emission factor for growing leaves of northern temperate forests $\left(0.67 \mu \mathrm{g} \mathrm{m}^{-2} \mathrm{~s}^{-1}\right)$ is close to our result $\left(0.76 \mu \mathrm{g} \mathrm{m}^{-2} \mathrm{~s}^{-1}\right)$.

In this model, dry depositions are accounted for by using a linear dependence of the deposition velocity on the LAI, 
increasing from 0 to $0.75 \mathrm{~cm} \mathrm{~s}^{-1}$ when LAI increases from 0 to $6 \mathrm{~m}^{2} \mathrm{~m}^{-2}$. Our results contrast with this parameterisation. Our calculated average deposition velocity $\left(2.4 \mathrm{~cm} \mathrm{~s}^{-1}\right)$ is 10 times higher than the mean deposition velocity observed by Karl et al. (2004) above a tropical rain forest $(0.27 \pm 0.14 \mathrm{~cm}$ $\mathrm{s}^{-1}$ ) and more than twice as high than the maximum velocity of $1.0 \mathrm{~cm} \mathrm{~s}^{-1}$ observed by Karl et al. (2005) above a Pinus taeda plantation and than the deposition velocity of $1.1 \pm 0.9 \mathrm{~cm} \mathrm{~s}^{-1}$ observed by Schade et al. (2010) above a Fagus sylvatica forest. However, it is worth mentioning that in our study we selected only wet atmospheric conditions (and $R_{\text {net }}>-20 \mathrm{~W} \mathrm{~m}^{-2}$ ) for the deposition velocity calculation (see Sect. 4.2), whereas other studies used their whole dataset. For comparison, we obtained a deposition velocity of $1.78 \pm 0.08 \mathrm{~cm} \mathrm{~s}^{-1}$ without filtering, still higher than in previous studies.

Our study therefore questions the measured and modelled net methanol budget in forest ecosystems. The presence of an adsorption/desorption process of methanol in water films and of a methanol degradation process could significantly modify the methanol budget on short- and long-term scales.

\subsection{Processes responsible for methanol depositions/emissions}

\subsubsection{Adsorption/desorption process}

The good agreement between our simulations and the measurements in summer, especially the good reproduction of the intra-day variability of the methanol exchange, suggests that methanol adsorption/desorption in water films is the main process controlling net methanol ecosystem exchange in the short-term. This is due to the high solubility of this compound in water compared with other BVOCs (Sander, 1999).

\subsubsection{Degradation processes}

In addition, the observation of a negative cumulated flux on a long-term scale in summer reflects the existence of methanol degradation processes in the ecosystem. Several degradation mechanisms have been identified in literature.

The possibility of stomatal deposition during the day followed by the oxidation of methanol into formaldehyde in the leaf was reported by Gout et al. (2000). However, this process would imply a higher deposition velocity during the day than at night, because the stomata are closed at night. Since no significant difference was observed in the deposition velocity during the day or night (Fig. 6), we assume that this process was negligible at our site compared with the adsorption/desorption mechanism in water films.

Another possibility would be consumption by methylotrophic bacteria, organisms that preferentially use methanol as source of energy and carbon through an enzymatic reaction (Duine and Frank, 1980). These organisms are known to be common on leaf surfaces (Holland and Polacco, 1994) and soil (Hiraishi et al., 1995). Romanovskaya et al. (2001) reported a natural colonization of methylotrophic bacteria on leaves, occurring mainly via air transfer. The degradation of methanol could also be due to the reaction of methanol in the aqueous-phase with $\mathrm{OH}$ radicals (Elliot and McCracken, 1989). This chemical reaction might occur in water films present on leaf and soil surfaces. Based on our sole dataset, we were not able to identify the precise origin of this degradation mechanism and whether it occurs on leaf and/or soil surfaces. Nevertheless, we found a mean degradation rate of $-47.42 \times 10^{-3} \mu \mathrm{g} \mathrm{m}^{-2} \mathrm{~s}^{-1}$ and a half lifetime for methanol in water films of $57.4 \mathrm{~h}$. This latter value is in agreement with Howard et al. (1991) who found a half lifetime in a wet soil of between 1 and 7 days.

\subsubsection{Biogenic emission processes}

We considered that biogenic emissions occur mainly in spring. Leaf methanol emission is usually considered to be two to three times lower for mature leaves than for young leaves (Karl et al., 2003; Nemecek-Marshall et al., 1995). It is therefore likely that, in summer, leaf emissions might be negligible compared with the methanol adsorption/desorption in water films. We therefore associated biogenic emission with the model residual only for spring.

Between 20 and 27 May (Fig. 10), these residuals showed an exponential increase with temperature (Fig. 11a), indicating an enzymatic mechanism and/or destorage from an internal pool. This enzymatic mechanism can be attributed to the demethylation of pectin that occurs during the leaf/needle cell wall expansion (Fall and Benson, 1996) and also to root growth (Folkers et al., 2008), this entire methanol production being emitted through the stomata (Galbally and Kirstine, 2002). In support of this hypothesis, the fitted temperature sensitivity factor was found to be $0.12 \pm 0.01{ }^{\circ} \mathrm{C}^{-1}$, comparable with previous enclosure studies $\left(\beta=0.06 \pm 0.003{ }^{\circ} \mathrm{C}^{-1}\right.$ (Fagus sylvatica) for Fillela et al., 2007 and $\beta=0.082^{\circ} \mathrm{C}^{-1}$ (Picea abies) for Folkers et al., 2008) (Filella et al., 2007; Folkers et al., 2008; Harley et al., 2007).

The attribution of biogenic emissions due to leaf/needle growth to a specific tree species is a difficult exercise because of the mixed composition of the stand. In the 20-27 May period, during which the most significant emissions were observed, footprint analysis reveals that a contribution to the total flux of $40 \%$ or more by Fagus sylvatica, Pseudotsuga menziesii and Picea abies/Abies alba occurred during 50, 36 and $24 \%$ of the time, respectively. Since Fagus sylvatica was the main contributor during this period and since its leaves were still not at their full development stage at that time, we attribute the main part of the growth-linked biogenic emission to that species, but we cannot exclude a contribution of Pseudotsuga menziesii and Picea abies/Abies alba, since they also contribute to flux and are known to have their bud break at the end of April and mid-May, respectively (Lebourgeois et al., 2002). 
The emission we observed (Fig. 10) did not coincide exactly with the Fagus sylvatica bud break, which started on 1 May 2010. This is probably because the following 15 days were characterized by cold conditions $\left(T_{\mathrm{a}}<9^{\circ} \mathrm{C}\right)$ which hindered biogenic emissions (Fig. 10). From 15 May onwards, the air temperature increased and the highest residuals were found.

Methanol can also be produced through litter decomposition occurring mainly in autumn (Gray et al., 2010; Warneke et al., 1999). This would agree with an increase of the model residuals observed in autumn, but we have already noted that our model was not designed to handle the LAI change occurring during this period. In the absence of trustworthy information produced by the model, it was not possible to determine if methanol production from the litter was really present in autumn and/or if a seasonal decrease of methanol degradation occurred.

In contrast to the enclosure study of Folkers et al. (2008) (Fagus sylvatica) and the DEC study of Brunner et al. (2007) (grassland), we did not observe any clear dependence of the biogenic emissions on PPFD, whereas PPFD is known to regulate stomatal conductance, which in turn controls leaf emissions for soluble compounds such as methanol (MacDonald and Fall, 1993; Niinemets et al., 2004). This dependence could have been blurred by two processes: (i) the biogenic emission computation procedure as model residuals standardised with air temperature and (ii) the leaf development dynamics that occurred throughout the period when biogenic emissions were analysed.

\section{Summary and conclusions}

This study presented and analysed long-term measurements of ecosystem-scale methanol exchange over a forest. It showed that the site behaved as a methanol sink for most of the measurement period, which contradicts results generally reported in experimental studies and the estimates of methanol exchanges based on emission modelling.

A simple model was developed in order to identify the mechanisms responsible for this sink. The results suggest that the main processes controlling methanol exchanges in summer are on a short-term scale, the methanol adsorption/desorption by water films and, at longer term, the methanol degradation.

The production of methanol associated with leaf development, as generally observed in some preceding studies, was also detected at our site, but it was limited to a short period in spring and did not constitute the largest contribution to the net ecosystem exchange. This would suggest that abiotic and methanol degradation processes play a more important role than previously assumed and that measurements focusing only on the growing period could strongly bias the annual methanol budget of ecosystems by neglecting these processes. This highlights the need to develop long-term measurements in order to obtain accurate estimates of net methanol exchanges at the ecosystem level.

Different processes responsible for methanol degradation and operating at the soil or leaf level were suggested, but none of them could ultimately be retained. Additional measurements are needed to elucidate the precise origin of this degradation.

These results suggest that the adsorption/desorption and degradation processes play a more important role than previously expected in the site methanol balance. In addition, these processes could affect other organic compounds that are similarly or more soluble than methanol as, for example, the precursors to secondary organic aerosol issue from isoprene oxidation, from aromatic compounds... This needs to be investigated for different types of ecosystems using longterm (at least one season) continuous measurements. The model and the procedure presented here could be adapted for each site and each compound in order to separate the abiotic and biogenic component of the fluxes.

Acknowledgements. This work was supported financially by the Belgian Science Policy Office (BELSPO) (contract number $\mathrm{SD} / \mathrm{TE} / 03 \mathrm{~A}$ ) for funding the IMPECVOC (Impact of Phenology and Environmental Conditions on BVOC Emissions from Forest Ecosystems) research project, and by the Fonds National de la Recherche Scientifique (FNRS) (contract number 2.4.575.08F) for the building of a new flux tower in Vielsalm.

The authors want to thank both reviewers: Lukas Hörtnagl and Thomas Holst for their time and constructive comments. We would like also to thank Thibault Hoffelt (Unit of Biosystem Physics of the University of Liege) and Maja Simpraga (Laboratory of Plant Ecology, Faculty of Bioscience Engineering, Ghent University) for their contributions to this work. We also wish to thank the technical personnel at the Unit of Biosystem Physics at the University of Liege, Gembloux Agro-Bio Tech (Michel Yernaux, Alain Debacq and Henri Chopin) and the technical personnel at the Belgian Institute for Space Aeronomy.

Edited by: J. Rinne

\section{References}

Ammann, C., Spirig, C., Neftel, A., Steinbacher, M., Komenda, M., and Schaub, A.: Application of PTR-MS for measurements of biogenic VOC in a deciduous forest, Int. J. Mass Spectrom., 239, 87-101, doi:10.1016/j.ijms.2004.08.012, 2004.

Atkinson, R.: Atmospheric chemistry of VOCs and $\mathrm{NO}_{\mathrm{x}}$, Atmos. Environ., 34, 2063-2101, doi:10.1016/s1352-2310(99)00460-4, 2000.

Aubinet, M., Grelle, A., Ibrom, A., Rannik, Ü., Moncrieff, J., Foken, T., Kowalski, A. S., Martin, P. H., Berbigier, P., Bernhofer, C., Clement, R., Elbers, J., Granier, A., Grünwald, T., Morgenstern, K., Pilegaard, K., Rebmann, C., Snijders, W., Valentini, R., and Vesala, T.: Estimates of the Annual Net Carbon and Water Exchange of Forests: The EUROFLUX Methodology, in: Advances in Ecological Research, edited by: Fitter, A. H., and Raffaelli, D. G., Academic Press, 113-175, 1999. 
Aubinet, M., Chermanne, B., Vandenhaute, M., Longdoz, B., Yernaux, M., and Laitat, E.: Long term carbon dioxide exchange above a mixed forest in the Belgian Ardennes, Agr. Forest Meteorol., 108, 293-315, doi:10.1016/s0168-1923(01)00244-1, 2001.

Aubinet, M., Heinesch, B., and Longdoz, B.: Estimation of the carbon sequestration by a heterogeneous forest: night flux corrections, heterogeneity of the site and inter-annual variability, Glob. Change Biol., 8, 1053-1071, doi:10.1046/j.13652486.2002.00529.x, 2002.

Aubinet, M., Vesala, T., and Papale, D.: Chapter 5: Night time flux correction, in: Eddy covariance: A practical guide to measurement and data analysis, Springer Verlag, 2012.

Bamberger, I., Hörtnagl, L., Schnitzhofer, R., Graus, M., Ruuskanen, T. M., Müller, M., Dunkl, J., Wohlfahrt, G., and Hansel, A.: BVOC fluxes above mountain grassland, Biogeosciences, 7 , 1413-1424, doi:10.5194/bg-7-1413-2010, 2010.

Brunner, A., Ammann, C., Neftel, A., and Spirig, C.: Methanol exchange between grassland and the atmosphere, Biogeosciences, 4, 395-410, doi:10.5194/bg-4-395-2007, 2007.

Burkhardt, J. and Eiden, R.: Thin water films on coniferous needles: A new device for the study of water vapour condensation and gaseous deposition to plant surfaces and particle samples, Atmos. Environ., 28, 2001-2011, doi:10.1016/1352-2310(94)90469-3, 1994.

Burkhardt, J., Flechard, C. R., Gresens, F., Mattsson, M., Jongejan, P. A. C., Erisman, J. W., Weidinger, T., Meszaros, R., Nemitz, E., and Sutton, M. A.: Modelling the dynamic chemical interactions of atmospheric ammonia with leaf surface wetness in a managed grassland canopy, Biogeosciences, 6, 67-84, doi:10.5194/bg-667-2009, 2009.

Custer, T. and Schade, G.: Methanol and acetaldehyde fluxes over ryegrass, Tellus B, 59, 673-684, doi:10.1111/j.16000889.2007.00294.x, 2007.

de Gouw, J. and Warneke, C.: Measurements of volatile organic compounds in the earth's atmosphere using proton-transferreaction mass spectrometry, Mass Spectrom. Rev., 26, 223-257, doi:10.1002/mas.20119, 2007.

Duine, A. and Frank Jr., J.: The prosthetic group of methanol dehydrogenase. Purification and some of its properties, Biochem. J., 187, 221-226, 1980.

Elliot, A. J. and McCracken, D. R.: Effect of temperature on $\mathrm{O}$ [solidus in circle] reactions and equilibria: A pulse radiolysis study, International Journal of Radiation Applications and Instrumentation. Part C. Radiation Physics and Chemistry, 33, 69-74, doi:10.1016/1359-0197(89)90096-9, 1989.

Fall, R. and Benson, A. A.: Leaf methanol - the simplest natural product from plants, Trends in Plant Science, 1, 296-301, doi:10.1016/s1360-1385(96)88175-0, 1996.

Filella, I., Wilkinson, M. J., Llusià, J., Hewitt, C. N., and Peñuelas, J.: Volatile organic compounds emissions in Norway spruce (Picea abies) in response to temperature changes, Physiologia Plantarum, 130, 58-66, doi:10.1111/j.1399-3054.2007.00881.x, 2007.

Foken, T.: Micrometeorology, Springer-Verlag, Berlin Heidelberg, 308 pp., 2008.

Foken, T. and Wichura, B.: Tools for quality assessment of surfacebased flux measurements, Agr. Forest Meteorol., 78, 83-105, doi:10.1016/0168-1923(95)02248-1, 1996.

Folkers, A., Hüve, K., Ammann, C., Dindorf, T., Kesselmeier, J.,
Kleist, E., Kuhn, U., Uerlings, R., and Wildt, J.: Methanol emissions from deciduous tree species: dependence on temperature and light intensity, Plant Biol., 10, 65-75, doi:10.1111/j.14388677.2007.00012.x, 2008.

Fowler, D., Pilegaard, K., Sutton, M. A., Ambus, P., Raivonen, M., Duyzer, J., Simpson, D., Fagerli, H., Fuzzi, S., Schjoerring, J. K., Granier, C., Neftel, A., Isaksen, I. S. A., Laj, P., Maione, M., Monks, P. S., Burkhardt, J., Daemmgen, U., Neirynck, J., Personne, E., Wichink-Kruit, R., Butterbach-Bahl, K., Flechard, C., Tuovinen, J. P., Coyle, M., Gerosa, G., Loubet, B., Altimir, N., Gruenhage, L., Ammann, C., Cieslik, S., Paoletti, E., Mikkelsen, T. N., Ro-Poulsen, H., Cellier, P., Cape, J. N., Horvath, L., Loreto, F., Niinemets, U., Palmer, P. I., Rinne, J., Misztal, P., Nemitz, E., Nilsson, D., Pryor, S., Gallagher, M. W., Vesala, T., Skiba, U., Brueggemann, N., Zechmeister-Boltenstern, S., Williams, J., O’Dowd, C., Facchini, M. C., de Leeuw, G., Flossman, A., Chaumerliac, N., and Erisman, J. W.: Atmospheric composition change: Ecosystems-Atmosphere interactions, Atmos. Environ., 43, 5193-5267, 2009.

Galbally, I. E. and Kirstine, W.: The Production of Methanol by Flowering Plants and the Global Cycle of Methanol, J. Atmos. Chem., 43, 195-229, doi:10.1023/a:1020684815474, 2002.

Gout, E., Aubert, S., Bligny, R., Rébeillé, F., Nonomura, A. R., Benson, A. A., and Douce, R.: Metabolism of Methanol in Plant Cells. Carbon-13 Nuclear Magnetic Resonance Studies, Plant Physiol., 123, 287-296, doi:10.1104/pp.123.1.287, 2000.

Gray, C. M., Monson, R. K., and Fierer, N.: Emissions of volatile organic compounds during the decomposition of plant litter, J. Geophys. Res.-Biogeo., 115, G03015, doi:10.1029/2010jg001291, 2010.

Harley, P., Greenberg, J., Niinemets, Ü., and Guenther, A.: Environmental controls over methanol emission from leaves, Biogeosciences, 4, 1083-1099, doi:10.5194/bg-4-1083-2007, 2007.

Heikes, B. G., Chang, W., Pilson, M. E. Q., Swift, E., Singh, H. B., Guenther, A., Jacob, D. J., Field, B. D., Fall, R., Riemer, D., and Brand, L.: Atmospheric methanol budget and ocean implication, Global Biogeochem. Cy., 16, 1133, doi:10.1029/2002gb001895, 2002.

Hiraishi, A., Furuhata, K., Matsumoto, A., Koike, K., Fukuyama, M., and Tabuchi, K.: Phenotypic and genetic diversity of chlorine-resistant Methylobacterium strains isolated from various environments, Appl. Environ. Microbiol., 61, 2099-2107, 1995.

Holland, M. A. and Polacco, J. C.: PPFMs and other covert contaminants - Is there more to plant physiology than just plant?, Annu. Rev. Plant Physiol. Plant Molec. Biol., 45, 197-209, 1994.

Holst, T., Arneth, A., Hayward, S., Ekberg, A., Mastepanov, M., Jackowicz-Korczynski, M., Friborg, T., Crill, P. M., and Bäckstrand, K.: BVOC ecosystem flux measurements at a high latitude wetland site, Atmos. Chem. Phys., 10, 1617-1634, doi:10.5194/acp-10-1617-2010, 2010.

Hörtnagl, L., Clement, R., Graus, M., Hammerle, A., Hansel, A., and Wohlfahrt, G.: Dealing with disjunct concentration measurements in eddy covariance applications: A comparison of available approaches, Atmos. Environ., 44, 2024-2032, doi:10.1016/j.atmosenv.2010.02.042, 2010.

Hörtnagl, L., Bamberger I., Graus M., Ruuskanen T. M., Schnitzhofer R., Müller M., Hansel A., and Wohlfahrt G.: Biotic, abiotic, and management controls on methanol exchange above 
a temperate mountain grassland, J. Geophys. Res., 116, G03021, doi:10.1029/2011JG001641, 2011.

Howard, P. H., Boethling, R. S., Jarvis, W. F., Meylan, W. M., and Michalenko, E. M.: Handbook of environmental degradation rates, Lewis Publishers, Chelsea, 1991.

Jacob, D. J., Field, B. D., Li, Q., Blake, D. R., de Gouw, J., Warneke, C., Hansel, A., Wisthaler, A., Singh, H. B., and Guenther, A.: Global budget of methanol: Constraints from atmospheric observations, J. Geophys. Res., 110, D08303, doi:10.1029/2004jd005172, 2005.

Karl, T., Guenther, A., Lindinger, C., Jordan, A., Fall, R., and Lindinger, W.: Eddy covariance measurements of oxygenated volatile organic compound fluxes from crop harvesting using a redesigned proton-transfer-reaction mass spectrometer, J. Geophys. Res., 106, 24157-24167, doi:10.1029/2000jd000112, 2001.

Karl, T. G., Spirig, C., Rinne, J., Stroud, C., Prevost, P., Greenberg, J., Fall, R., and Guenther, A.: Virtual disjunct eddy covariance measurements of organic compound fluxes from a subalpine forest using proton transfer reaction mass spectrometry, Atmos. Chem. Phys., 2, 279-291, doi:10.5194/acp-2-279-2002, 2002.

Karl, T., Guenther, A., Spirig, C., Hansel, A., and Fall, R.: Seasonal variation of biogenic VOC emissions above a mixed hardwood forest in northern Michigan, Geophys. Res. Lett., 30, 2186, doi:10.1029/2003gl018432, 2003.

Karl, T., Potosnak, M., Guenther, A., Clark, D., Walker, J., Herrick, J. D., and Geron, C.: Exchange processes of volatile organic compounds above a tropical rain forest: Implications for modeling tropospheric chemistry above dense vegetation, J. Geophys. Res., 109, D18306, doi:10.1029/2004jd004738, 2004.

Karl, T., Harley, P., Guenther, A., Rasmussen, R., Baker, B., Jardine, K., and Nemitz, E.: The bi-directional exchange of oxygenated VOCs between a loblolly pine (Pinus taeda) plantation and the atmosphere, Atmos. Chem. Phys., 5, 3015-3031, doi:10.5194/acp-5-3015-2005, 2005.

Kormann, R. and Meixner, F.: An Analytical Footprint Model For Non-Neutral Stratification, Bound.-Lay. Meteorol., 99, 207-224, doi:10.1023/a:1018991015119, 2001.

Laffineur, Q., Aubinet, M., Schoon, N., Amelynck, C., Müller, J. F., Dewulf, J., Van Langenhove, H., Steppe, K., Simpraga, M., and Heinesch, B.: Isoprene and monoterpene emissions from a mixed temperate forest, Atmos. Environ., 45, 3157-3168, doi:10.1016/j.atmosenv.2011.02.054, 2011.

Laitat, E., Chermanne, B., and Portier, B.: Biomass, carbon and nitrogen allocation in open top chambers under ambient and elevated $\mathrm{CO}_{2}$ and in a mixed forest stand. A tentative approach for scaling up from the experiments of Vielsalm, in: Forest Ecosystem Modelling, Upscaling and Remote Sensing., edited by: Ceulemans, R. J. M., Veroustraete F., Gond V., and Van Rensbergen J. B. H. F., Academic Publishing, The Hague, The Netherlands, 33-60, 1999.

Langford, B., Misztal, P. K., Nemitz, E., Davison, B., Helfter, C., Pugh, T. A. M., MacKenzie, A. R., Lim, S. F., and Hewitt, C. N.: Fluxes and concentrations of volatile organic compounds from a South-East Asian tropical rainforest, Atmos. Chem. Phys., 10, 8391-8412, doi:10.5194/acp-10-8391-2010, 2010.

Lebourgeois, F., Differt, J., Granier, A., Breda, N., and Ulrich, E.: Premières observations phénologiques des peuplements du réseau national de suivi à long terme des écosystèmes forestiers
(RENECOFOR, France), Revue Forestière Française, 54, 407408, 2002.

Lindinger, W., Hansel, A., and Jordan, A.: On-line monitoring of volatile organic compounds at pptv levels by means of protontransfer-reaction mass spectrometry (PTR-MS) medical applications, food control and environmental research, Int. J. Mass Spectrom. and Ion Processes, 173, 191-241, doi:10.1016/s01681176(97)00281-4, 1998.

MacDonald, R. C. and Fall, R.: Detection of substantial emissions of methanol from plants to the atmosphere, Atmos. Environ.. Part A. General Topics, 27, 1709-1713, doi:10.1016/09601686(93)90233-o, 1993.

Mihailovic, D., Alapaty, K., and Podrascanin, Z.: Chemical transport models, Environ. Sci. Pollut. Res., 16, 144-151, doi:10.1007/s11356-008-0086-0, 2009.

Millet, D. B., Jacob, D. J., Custer, T. G., de Gouw, J. A., Goldstein, A. H., Karl, T., Singh, H. B., Sive, B. C., Talbot, R. W., Warneke, C., and Williams, J.: New constraints on terrestrial and oceanic sources of atmospheric methanol, Atmos. Chem. Phys., 8, 68876905, doi:10.5194/acp-8-6887-2008, 2008.

Neftel, A., Spirig, C., and Ammann, C.: Application and test of a simple tool for operational footprint evaluations, Environ. Pollut., 152, 644-652, doi:10.1016/j.envpol.2007.06.062, 2008.

Nemecek-Marshall, M., MacDonald, R. C., Franzen, J. J., Wojciechowski, C. L., and Fall, R.: Methanol Emission from Leaves (Enzymatic Detection of Gas-Phase Methanol and Relation of Methanol Fluxes to Stomatal Conductance and Leaf Development), Plant Physiol., 108, 1359-1368, doi:10.1104/pp.108.4.1359, 1995.

Nicholson, D.: What is going up in smoke?, Journal of Forestry Research, 14, 162-166, doi:10.1007/bf02856786, 2003.

Niinemets, U., Loreto, F., and Reichstein, M.: Physiological and physicochemical controls on foliar volatile organic compound emissions, Trends in Plant Science, 9, 180-186, 2004.

Pul, W. A. J. and Jacobs, A. F. G.: The conductance of a maize crop and the underlying soil to ozone under various environmental conditions, Bound.-Lay. Meteorol., 69, 83-99, doi:10.1007/bf00713296, 1994.

Richardson, A. D., Hollinger, D. Y., Burba, G. G., Davis, K. J., Flanagan, L. B., Katul, G. G., William Munger, J., Ricciuto, D. M., Stoy, P. C., Suyker, A. E., Verma, S. B., and Wofsy, S. C.: A multi-site analysis of random error in tower-based measurements of carbon and energy fluxes, Agr. Forest Meteorol., 136, 1-18, doi:10.1016/j.agrformet.2006.01.007, 2006.

Rinne, H. J. I., Guenther, A. B., Warneke, C., de Gouw, J. A., and Luxembourg, S. L.: Disjunct eddy covariance technique for trace gas flux measurements, Geophys. Res. Lett., 28, 3139-3142, doi:10.1029/2001gl012900, 2001.

Romanovskaya, V. A., Stolyar, S. M., Malashenko, Y. R., and Dodatko, T. N.: The Ways of Plant Colonization by MethylobacteriumStrains and Properties of These Bacteria, Microbiology, 70, 221-227, doi:10.1023/a:1010441900060, 2001.

Sander, R.: Compilation of Henry's law constants for inorganic and organic species of potential importance in environmental chemistry (Version 3), available at: http://www.mpch-mainz.mpg.de/ $\sim_{\text {sander/res/henry.html, } 1999 .}$

Schade, G. W. and Goldstein, A. H.: Fluxes of oxygenated volatile organic compounds from a ponderosa pine plantation, J. Geophys. Res., 106, 3111-3123, doi:10.1029/2000jd900592, 2001. 
Schade, G. W. and Goldstein, A. H.: Seasonal measurements of acetone and methanol: Abundances and implications for atmospheric budgets, Global Biogeochem. Cy., 20, GB1011, doi:10.1029/2005gb002566, 2006.

Schade, G., Solomon, S., Dellwik, E., Pilegaard, K., and LadstätterWeissenmayer, A.: Methanol and other VOC fluxes from a Danish beech forest during late springtime, Biogeochemistry, 106, 337-355, doi:10.1007/s10533-010-9515-5, 2011.

Seco, R., Peñuelas, J., and Filella, I.: Short-chain oxygenated VOCs: Emission and uptake by plants and atmospheric sources, sinks, and concentrations, Atmos. Environ., 41, 2477-2499, doi:10.1016/j.atmosenv.2006.11.029, 2007.

Singh, H., Chen, Y., Tabazadeh, A., Fukui, Y., Bey, I., Yantosca, R., Jacob, D., Arnold, F., Wohlfrom, K., Atlas, E., Flocke, F., Blake, D., Blake, N., Heikes, B., Snow, J., Talbot, R., Gregory, G., Sachse, G., Vay, S., and Kondo, Y.: Distribution and fate of selected oxygenated organic species in the troposphere and lower stratosphere over the Atlantic, J. Geophys. Res., 105, 3795-3805, doi:10.1029/1999jd900779, 2000.

Singh, H., Chen, Y., Staudt, A., Jacob, D., Blake, D., Heikes, B., and Snow, J.: Evidence from the Pacific troposphere for large global sources of oxygenated organic compounds, Nature, 410, 1078-1081, 2001.

Spirig, C., Neftel, A., Ammann, C., Dommen, J., Grabmer, W., Thielmann, A., Schaub, A., Beauchamp, J., Wisthaler, A., and Hansel, A.: Eddy covariance flux measurements of biogenic VOCs during ECHO 2003 using proton transfer reaction mass spectrometry, Atmos. Chem. Phys., 5, 465-481, doi:10.5194/acp-5-465-2005, 2005.
Stavrakou, T., Guenther, A., Razavi, A., Clarisse, L., Clerbaux, C., Coheur, P.-F., Hurtmans, D., Karagulian, F., De Maziére, M., Vigouroux, C., Amelynck, C., Schoon, N., Laffineur, Q., Heinesch, B., Aubinet, M., Rinsland, C., and Müller, J.-F.: First space-based derivation of the global atmospheric methanol emission fluxes, Atmos. Chem. Phys., 11, 4873-4898, doi:10.5194/acp-11-4873-2011, 2011.

Sutton, M. A., Burkhardt, J. K., Guerin, D., Nemitz, E., and Fowler, D.: Development of resistance models to describe measurements of bi-directional ammonia surface-atmosphere exchange, Atmos. Environ., 32, 473-480, doi:10.1016/s1352-2310(97)001647, 1998.

Taipale, R., Ruuskanen, T. M., and Rinne, J.: Lag time determination in DEC measurements with PTR-MS, Atmos. Meas. Tech., 3, 853-862, doi:10.5194/amt-3-853-2010, 2010.

Tie, X., Guenther, A., and Holland, E.: Biogenic methanol and its impacts on tropospheric oxidants, Geophys. Res. Lett., 30, 1881, doi:10.1029/2003g1017167, 2003.

Van Hove, L. W. A. and Adema, E. H.: The effective thickness of water films on leaves, Atmos. Environ., 30, 2933-2936, doi:10.1016/1352-2310(96)00012-x, 1996.

Warneck, P.: A note on the temperature dependence of Henry's Law coefficients for methanol and ethanol, Atmos. Environ., 40, 7146-7151, doi:10.1016/j.atmosenv.2006.06.024, 2006.

Warneke, C., Karl, T., Judmaier, H., Hansel, A., Jordan, A., Lindinger, W., and Crutzen, P. J.: Acetone, methanol, and other partially oxidized volatile organic emissions from dead plant matter by abiological processes: Significance for atmospheric $\mathrm{HO}_{\mathrm{x}}$ chemistry, Global Biogeochem. Cy., 13, 9-17, 1999. 